\title{
Life-With-Hope Sentencing
}

\section{The Argument for Replacing Life-Without-Parole Sentences with Presumptive Life Sentences}

\begin{abstract}
WILLIAM W. BERRY III*
The United States has over forty-one thousand people serving lifewithout-parole (LWOP) sentences. It is a phenomenon unparalleled in the history of the world. This rise is attributable to a strange confluence of (1) the increasing use of LWOP as an alternative to the death penalty, (2) abolition of parole by states as part of truth-insentencing reforms, and (3) the rise in mandatory minimum sentences, particularly related to sale and distribution of illegal drugs. Nowhere has a state or federal government examined the appropriateness of LWOP sentences or developed a framework to assess whether an offender warrants such a sentence.
\end{abstract}

Given the historical thoughtlessness of determining who receives this serious punishment and the wild increase in such sentences, LWOP sentences clearly need reform. This Article attempts to address this epidemic by demonstrating the shortcomings of LWOP and proposing an alternative sentencing model for serious offenders.

This Article, then, argues for the abolition of LWOP sentences. Specifically, the human rights implications of such sentences, the speculative nature of such sentences, and the presence of other sufficient alternatives provide justification for the abandoning of LWOP sentences. Instead, this Article advocates for the adoption of presumptive life sentences as an alternative to $L W O P$.

In Part II, the Article describes the current LWOP crisis. Part III of this Article makes the case for abolishing LWOP sentences. Finally, in Part IV, the Article proposes the adoption of presumptive life sentences as a feasible alternative to $L W O P$, and demonstrates how such sentences can replace $L W O P$ and end the LWOP epidemic.

* Associate Professor of Law and Jessie D. Puckett Lecturer, University of Mississippi. D. Phil., Oxford (UK); J.D., Vanderbilt; B.A, Virginia. The author would like to thank the following for comments on various iterations and drafts of this article: Carissa Hessick, Meghan Ryan, John Stinneford, Lea Johnston, Douglas Berman, Jack Wade Nowlin, Stacey Lantagne, Farish Percy, Chad Flanders, and participants at the Southern Methodist University Law Criminal Justice Conference. The author would also like to thank Nicole Jones for her outstanding research assistance. 


\section{TABLE OF CONTENTS}

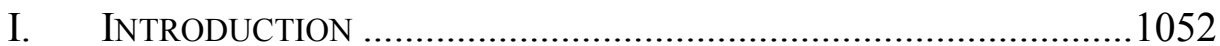

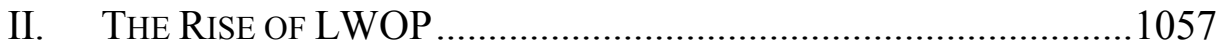

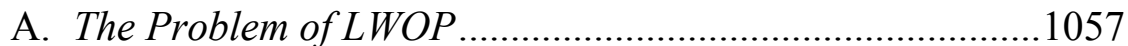

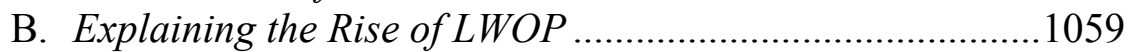

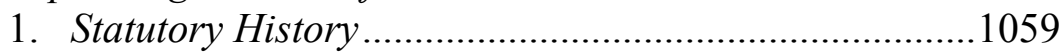

2. LWOP and the Death Penalty .......................................1061

3. LWOP and Parole Abolition ............................................1062

4. LWOP, Penal Populism, and Mandatory Sentences.....1063

C. Why LWOP Deserves Heightened Scrutiny …………….......1064

III. THE ARGUMENT FOR LWOP ABOLITION ......................................1068

A. LWOP Sentences Violate Human Rights .............................1068

B. LWOP Sentences Are Cruel and Unusual Punishments .....1072

1. The European Court of Human Rights ..........................1073

2. The Evolving Standards of Decency ...............................1074

C. The Presence of Reasonable Alternatives ...........................1079

1. Time Is on the State's Side............................................1079

2. The Limits of Sentencing at Trial...................................1080

IV. Presumptive Life Sentences as the LWOP

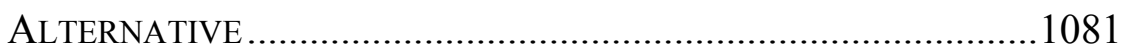

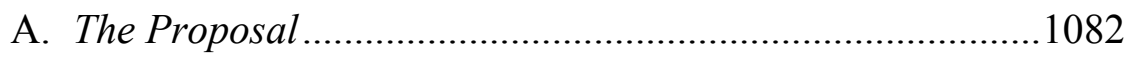

B. Why the Proposal Cures the LWOP Epidemic ...................1083

C. The Risks of the Proposal (and Why They Are Worth

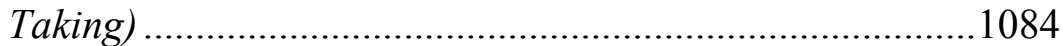

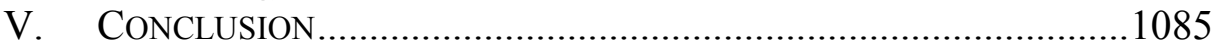

\section{INTRODUCTION}

Death is much easier to take than continuing the barren and hopeless existence of so-called life in prison. ${ }^{1}$

Life-without-parole (LWOP) ${ }^{2}$ is the third rail of criminal punishments. ${ }^{3}$ Conservatives take comfort in the existence of a punishment that will allow the

\footnotetext{
${ }^{1}$ Christy Chandler, Voluntary Executions, 50 Stan. L. REv. 1897, 1898 (1998) (citing William Carlsen, State High Court Overturns 2 More Death Sentences, SAN DIEGO UNION-TRIB., Dec. 24, 1985, at A6 (quoting Robert Lee Massie upon receiving his second death sentence, who tried to waive his appeal to "get it over with")).

${ }^{2}$ An LWOP sentence means that the sentence of the offender is to die in prison, with no possibility of release. LWOP sentences are sometimes called "flat life," "natural life," or "whole life" sentences. See Marc Mauer et Al., The Sentencing Project, The MeAning OF "LIFE": LONG PRISON Sentences IN CONTEXT 4 (May 2004), http://www.sentencingproject.org/doc/publications/inc_meaningoflife.pdf [http://perma.cc/
} 
state to lock away evil criminal offenders forever. As Steven Brill explained, "I ... think we're insanely permissive about murderers. Liberals ought to understand that parole for murderers - parole of any kind for any murderersis at least as disrespectful of the sanctity of human life as the death penalty is. Besides, it's just plain crazy."4

Liberals equally embrace LWOP, but for a different reason-LWOP diminishes the use of the death penalty. ${ }^{5}$ Indeed, since the widespread adoption of LWOP in the mid-1990s, the imposition of new capital sentences and the number of executions have declined to levels not seen since the 1970s. ${ }^{6}$

But LWOP may be, in some ways, the most serious punishment of all. ${ }^{7} \mathrm{~A}$ "civil death," 8 an LWOP sentence removes all hope for life outside of prison

7633-4SZB]; DiRK VAN ZYL SMIT, TAKING LIFE IMPRISONMENT SERIOUSLY IN NATIONAL AND INTERNATIONAL LAW 1 (2002). "Death-in-prison" or "a civil death" is perhaps a more accurate way of characterizing LWOP sentences. See Michael M. O'Hear, The Beginning of the End for Life Without Parole?, 23 FED. SENT'G REP. 1, 5 (2010). See generally Bryan SteVEnson, Just Mercy: A Story of Justice And REDEMPtion (2014).

${ }^{3}$ With apologies to social security, the third rail in a railway is the exposed electrical conductor that carries high voltage power, and stepping on the third rail usually results in electrocution. See, e.g., Electro-Magnetic Railway, U.S. Patent No. 263,132 (filed Aug. 19, 1880) (Thomas Edison's third rail patent). Indeed, the third rail seems like a logical metaphor when exploring the propriety of criminal sentences with terminal consequences, albeit not as sudden.

${ }^{4}$ Danya W. Blair, A Matter of Life and Death: Why Life Without Parole Should Be a Sentencing Option in Texas, 22 AM. J. CRIM. L. 191, 205 n.66 (1994) (quoting Steven Brill, Throw Away the Key, AM. L., July-Aug. 1987, at 3).

${ }^{5}$ Carol S. Steiker \& Jordan M. Steiker, Opening a Window or Building a Wall? The Effect of Eighth Amendment Death Penalty Law and Advocacy on Criminal Justice More Broadly, 11 U. PA. J. Const. L. 155, 158, 175 (2008); Note, A Matter of Life and Death: The Effect of Life-Without-Parole Statutes on Capital Punishment, 119 HaRV. L. REV. 1838, 1838 (2006) [hereinafter Harvard Note].

${ }^{6}$ See Harvard Note, supra note 5, at 1838, 1851-52. See generally Year That States Adopted Life Without Parole (LWOP) Sentencing, DeAth Penalty InFo. CTR. (Aug. 2, 2010), http://www.deathpenaltyinfo.org/year-states-adopted-life-without-parole-lwop-sentencing [http://perma.cc/HVP8-94FB] [hereinafter State Adoption of LWOP].

7 See, e.g., CESARE BECCARIA, ON CRIMES AND PUNISHMENTS 71-76 (5th ed. 2009) (1764) (arguing that LWOP sentences were harsher than the death penalty); John Stuart Mill, Speech in Favor of Capital Punishment Before Parliament (Apr. 21, 1868), http://ethics.sandiego.edu/Books/Mill/Punishment [http://perma.cc/MT9R-LJL2] ("What comparison can there really be, in point of severity, between consigning a man to the short pang of a rapid death, and immuring him in a living tomb, there to linger out what may be a long life in the hardest and most monotonous toil, without any of its alleviations or rewards--debarred from all pleasant sights and sounds, and cut off from all earthly hope, except a slight mitigation of bodily restraint, or a small improvement of diet?"); see also Craig S. Lerner, Life Without Parole as a Conflicted Punishment, 48 WAKE Forest L. REV. 1101, 1103 (2013) (discussing Beccaria's and Mill's views about the death penalty and life without parole, and citing both).

${ }^{8} \mathrm{O}$ 'Hear, supra note 2 , at 5. 
for the criminal offender. ${ }^{9}$ It is a communication from society that one is irredeemable, because one either deserves death in prison or has no hope for change. ${ }^{10}$ This eternal banishment means that the offender must simply wait to die. ${ }^{11}$

For some, an LWOP sentence is worse than a death sentence, as death sentences at least mark an anticipated end to suffering. ${ }^{12}$ The large number of "volunteers" for executions - death row inmates who waive their appeals to accelerate their execution date-supports this notion that life in prison is worse than death. ${ }^{13}$

The psychological suffering that often accompanies LWOP sentences is not surprising. ${ }^{14}$ The absence of external human contact, both physical and emotional, weighs heavily on many offenders. In some cases, such isolation causes permanent psychological damage. ${ }^{15}$ This is particularly true when LWOP offenders spend significant amounts of time in solitary confinement. ${ }^{16}$

In any event, the current use of LWOP by the United States is unprecedented in the history of the world. ${ }^{17}$ Without a doubt, it is a growing epidemic, with the number of LWOP sentences tripling from 12,453 in 1992 to

\footnotetext{
${ }^{9}$ Naovarath v. State, 779 P.2d 944, 944, 947 (Nev. 1989).

${ }^{10}$ Graham v. Florida, 560 U.S. 48, 74 (2010) ("By denying the defendant the right to reenter the community, the State makes an irrevocable judgment about that person's value and place in society.").

${ }^{11}$ See, e.g., Catherine Appleton \& Bent Grøver, The Pros and Cons of Life Without Parole, 47 BRIT. J. CRIMINOLOGY 597, 611 (2007) ("[Life without parole] removes any prospect of reward for change and is therefore fundamentally inhumane. If society is going to announce baldly that we don't care what you do, we don't care what programmes you engage in, you're never going to be released, it's the equivalent of providing a death sentence.").

${ }^{12}$ See Mary Pat Treuthart et al., Mitigation Evidence and Capital Cases in Washington: Proposals for Change, 26 SeAtTLE U. L. REV. 241, 268 (2002).

13 Indeed, a "remarkable 123 prisoners-11\% of the 1,099 executions carried out [through the end of 2008] - have dropped their appeals and allowed themselves to be killed." Robert Johnson \& Sandra McGunigall-Smith, Life Without Parole, America's Other Death Penalty, 88 PRISON J. 328, 333 (2008), http://www.realcostofprisons.org/ materials/americas_other_death_penalty.pdf [http://perma.cc/W2RU-SALR].

${ }^{14}$ Wayne A. Logan, Proportionality and Punishment: Imposing Life Without Parole on Juveniles, 33 WAKE FOREST L. REV. 681, 712 n.143 (1998) (citing cases where inmates preferred death sentences to terms of life in prison); see also Welsh S. White, Defendants Who Elect Execution, 48 U. PITT. L. REV. 853, 855-61 (1987).

15 Johnson \& McGunigall-Smith, supra note 13, at 336.

${ }^{16}$ See, e.g., Andrew Cohen, Half a Life in Solitary: How Colorado Made a Young Man Insane, ATLANTIC (Nov. 13, 2013), http://www.theatlantic.com/national/archive/2013/ 11/half-a-life-in-solitary-how-colorado-made-a-young-man-insane/281306/ [http://perma.cc/ 693A-W49F].

17 See Nicole Flatow, One in Nine U.S. Prisoners Are Serving Life Sentences, Report Finds, THINKPROGRESS (Sept. 19, 2013), http://thinkprogress.org/justice/2013/09/19/2645 781/prisoners-serving-life-sentences/ [http://perma.cc/77RL-SDML].
} 
over 41,000 presently. ${ }^{18}$ In some states, LWOP sentences comprise more than five percent of the prison population. ${ }^{19}$ And many of the individuals serving LWOP sentences did not commit violent crimes. ${ }^{20}$

As with many problems in our legal system, the LWOP epidemic resulted from a confluence of different events. ${ }^{21}$ It certainly is not the product of any intentional or thoughtful legislative design.

Three factors are primarily responsible. First, beginning in the mid-1980s, the war on drugs and the rise of penal populism began a trend resulting in the adoption of harsher sentences, including LWOP sentences. ${ }^{22}$ As a result, many states adopted LWOP as a sentencing option in the $1990 \mathrm{~s} .{ }^{23}$

As part of this move to harsher punishments, some states and the federal government have also adopted mandatory LWOP sentences. ${ }^{24}$ An overwhelming majority of states-thirty-seven-use mandatory LWOP sentences for some crimes. ${ }^{25}$

Second, the truth-in-sentencing movement contributed to the increase in LWOP sentences. ${ }^{26}$ Specifically, the perception that offenders served

18 Ashley Nellis \& Ryan S. King, The Sentencing Project, No Exit: The EXPANDING USE OF LIFE SENTENCES IN AMERICA 7 (July 2009), http://sentencing project.org/doc/publications/publications/inc_NoExitSept2009.pdf [http://perma.cc/A7S26CEH]; Ashley Nellis, Throwing Away the Key: The Expansion of Life Without Parole Sentences in the United States, 23 FED. SENT'G REP. 27, 27 (2010).

${ }^{19}$ Nellis, supra note 18 , at 28.

${ }^{20}$ See, e.g., ACLU, A Living DeAth: Life Without Parole for Nonviolent OFFENSES 2 (Nov. 2013), https://www.aclu.org/sites/default/files/assets/111813-lwop-completereport.pdf [http://perma.cc/6KW2-VHUT].

21 See Ashley Nellis, The Sentencing Project, Life Goes On: The Historic Rise OF LIFE SENTENCES IN AMERICA 3-4 (2013), http://sentencingproject.org/doc/publications/ inc_Life $\% 20 \mathrm{Goes} \% 20 \mathrm{On} \% 202013 . p d f$ [http://perma.cc/24HQ-NTN8]; Flatow, supra note 17, at para. 5; Mike Riggs, The Dramatic Rise of Life Without Parole, in 3 Charts, ATLANTIC: CiTYLAB (Sept. 18, 2013), http:/www.citylab.com/politics/2013/09/1-9-americanprisoners-has-been-sentenced-die-behind-bars/6944/ [http://perma.cc/FB53-CMQA].

22 See ACLU, supra note 20, at 33.

23 See State Adoption of LWOP, supra note 6.

24 See U.S. SENTENCING COMM'N, REPORT TO THE CONGRESS: MANDATORY Minimum Penalties in the Federal Criminal Justice System 63 (Oct. 2011), http:/www.ussc.gov/news/congressional-testimony-and-reports/mandatory-minimum-penalties/ report-congress-mandatory-minimum-penalties-federal-criminal-justice-system [http://perma.cc/ 8QA5-5GR3] ("Statutes carrying mandatory minimum penalties have increased in number, apply to more offense conduct, require longer terms, and are used more often than they were 20 years ago. These changes have occurred amid other systemic changes to the federal criminal justice system,... [including] expanded federalization of criminal law, increased size and changes in the composition of the federal criminal docket, high rates of imposition of sentences of imprisonment, and increasing average sentence lengths.... [T] he changes to mandatory minimum penalties and these co-occurring systemic changes have combined to increase the federal prison population significantly.").

25 Id.; see Nellis, supra note 18 , at 27.

${ }^{26}$ See, e.g., Paula M. DitTon \& Doris James Wilson, U.S. DeP'T of Justice, Bureau of Justice Statistics, Special Report: Truth in SEntencing in State Prisons 
significantly less time than the length of their sentences because of lenient parole boards resulted in many states abolishing parole. ${ }^{27}$ Life sentences, formerly fifteen-year sentences in many cases, became LWOP sentences, leading to a boom in LWOP sentences. ${ }^{28}$

Third, the adoption of LWOP sentences in the 1990s resulted in its juxtaposition with the death penalty in many cases, providing a logical alternative. ${ }^{29}$ Because LWOP sentences did not result in executions, many states made this sentence the only alternative sentencing option for offenders convicted of capital crimes. ${ }^{30}$

Given the historical thoughtlessness of determining who receives this serious punishment and the wild increase in such sentences, LWOP sentences clearly need reform. Moving onto this "third rail," this Article attempts to fill that void by exploring the shortcomings of LWOP and proposing an alternative sentencing model for serious offenders.

This Article, then, argues for the abolition of LWOP sentences. Specifically, the human rights implications of such sentences, the speculative nature of such sentences, and the presence of other alternatives provide justification for the abandoning of LWOP. Further, to fill the void left by the abolition of LWOP, this Article advocates for the adoption of presumptive life sentences as an alternative to LWOP.

In Part II, the Article describes the current LWOP crisis. Part III of this Article makes the case for abolishing LWOP sentences. Finally, in Part IV, the Article proposes the adoption of presumptive life sentences as a feasible alternative to life without parole, and demonstrates how such sentences can replace LWOP and end the LWOP epidemic.

13-14 (Jan. 1999), http://citeseerx.ist.psu.edu/viewdoc/download?rep=rep1\&type=pdf\&doi $=10.1 .1 .160 .1569$ [http://perma.cc/A3W4-3XVR].

27 See, e.g., Timothy A. Hughes et AL., U.S. Dep't of Justice, Bureau OF Justice Statistics, Special Report: Trends in State Parole, 1990-2000, at 2 (Oct. 2001), http://www.prisonpolicy.org/scans/bjs/tsp00.pdf [http://perma.cc/862S-TA7P].

28 See, e.g., William J. Sabol et Al., Urban Inst., Justice Policy Ctr., Research REPort: The Influences of TRUTH-IN-SENTENCING REFORMS on ChANGES IN STATES' Sentencing Practices And Prison Populations 10 (Apr. 2002); Susan Turner et al., The Impact of Truth-in-Sentencing and Three Strikes Legislation: Prison Populations, State Budgets, and Crime Rates, 11 STAN. L. \& POL'Y REV. 75, 76 (1999).

${ }^{29}$ See Harvard Note, supra note 5, at 1838.

${ }^{30}$ Indeed, twenty-seven states have mandatory LWOP sentences for at least one crime. CONNIE DE LA VeGa ET AL., UniV. OF S.F. SCH. OF LAW, CTR. FOR LAW \& Global Justice, Cruel and Unusual: U.S. Sentencing Practices in a Global Context 22 (May 2012), http://www.usfca.edu/sites/default/files/law/cruel-and-unusual.pdf [http://perma.cc/ D6UD-88MQ]. 


\section{THE RISE OF LWOP}

\section{A. The Problem of $L W O P$}

The imposition of an LWOP sentence expresses one of two different sentiments. ${ }^{31}$ First, from a retributive perspective, it communicates that the offender's crime warrants death in prison because of his culpability and the harm he inflicted. ${ }^{32}$ Second, from a utilitarian perspective, it communicates the determination that the offender is irredeemable, and can never be fit to rejoin society. ${ }^{33}$ For one or both of these reasons, the state condemns him to die in prison. ${ }^{34}$

In imposing such a sentence, the court makes a one-time decision that, for the offender, has lifelong significance. Courts rarely, if ever, revisit LWOP sentences. ${ }^{35}$ Indeed, the assumption of an LWOP sentence is that the state has nothing further to consider with respect to the offender, save providing for a cell, food, and limited health care. ${ }^{36}$

In making these kinds of decisions - that the offender deserves to die in prison and will never be suitable to rejoin society - courts often rely heavily on an assessment of the offender's criminal behavior. ${ }^{37}$ These assessments typically do not phrase their inquiry in terms of mental health, likelihood for rehabilitation, or other mitigating factors. ${ }^{38}$

Most importantly, the court's decision forecloses any future consideration of the offender as a person. ${ }^{39}$ It is the harsh nature of this snapshot decisionthat at this particular point in time there is no hope for redemption-coupled with its severe consequence-death in a prison cell-that warrants further scrutiny. 40

On some level, it seems presumptuous to judge the future capability of a person to find some sort of personal redemption and ability to improve his behavior to an acceptable level. Perhaps some crimes, the most heinous and brutal, indicate that an offender is beyond redemption, but those must be

${ }^{31}$ See Appleton \& Grøver, supra note 11, at 603.

${ }^{32}$ See id. at 605.

${ }^{33}$ See id. at $603-04$.

${ }^{34}$ See id. at 603.

${ }^{35}$ This is unlike capital cases, where the reversal rate is almost seventy percent. See Andrew Gelman et al., A Broken System: The Persistent Patterns of Reversals of Death Sentences in the United States, 1 J. EMPIRICAL Legal Stud. 209, 260 (2004).

${ }^{36}$ See Appleton \& Grøver, supra note 11, at 611.

${ }^{37}$ See id. at $610-11$.

${ }^{38}$ See Nellis, supra note 18 , at 30.

${ }^{39}$ See id.

${ }^{40}$ See, e.g., Vinter v. United Kingdom, 2013-III Eur. Ct. H.R. 317, 324 (holding that LWOP sentences violate human rights); Appleton \& Grøver, supra note 11, at 612. 
few. ${ }^{41}$ Assessing the human capacity for personal growth and change in a particular situation is certainly a speculative science at best. ${ }^{42}$

Even worse, courts make these decisions about the offender's potential for redemption in the shadow of the crime he committed. ${ }^{43}$ The emotional reaction to the harm caused by the offender often denies him, perhaps properly, any sympathies of the court. ${ }^{44}$ Instead, courts sometimes make such sentencing decisions in the heat of the moment and the presence of the victims, making careful consideration of the future prospects of the offender all the more difficult. ${ }^{45}$

And often, courts do not even get to make such decisions. Many LWOP sentences are mandatory, which means that the legislature decides the sentence without respect to the character of the individual person at all. ${ }^{46}$ If society is to declare a citizen irredeemable, it seems particularly unfair that the citizen has no opportunity to challenge the imposition of the sentence or speak to its merits. ${ }^{47}$ The automatic nature of mandatory LWOP sentences cheats the offender of the opportunity to explain why his life might still have worth to society. ${ }^{48}$ At the very least, such offenders should have an opportunity to plead for the mercy of the court. 49

Given both the volume of LWOP sentences and the routine, perfunctory nature in which legislatures and courts promulgate these punishments, it is unlikely the growing wave of LWOP sentences in the United States will subside in the near future without increased awareness of the consequences of

${ }^{41}$ Furman v. Georgia, 408 U.S. 238, 286 (1972) (Brennan, J., concurring) ("Death is a unique punishment in the United States. .. . [T] hose States that still inflict death reserve it for the most heinous crimes.").

42 Compare Miller v. Alabama, 132 S. Ct. 2455, 2469 (2012), with Graham v. Florida, 560 U.S. 48, 68 (2010) (both indicating the possibility of juveniles changing over time); William W. Berry III, Ending Death by Dangerousness, 52 ARIZ. L. REV. 889, 907 (2010).

${ }^{43}$ Angela S. Ahola et al., Is Justice Really Blind? Effects of Crime Descriptions, Defendant Gender and Appearance, and Legal Practitioner Gender on Sentences and Defendant Evaluations in a Mock Trial, 17 PSYCHIATRY PSYCHOL. \& L. 304, 304-06 (2010); William Samuel \& Elizabeth Moulds, The Effect of Crime Severity on Perceptions of Fair Punishment: A California Case Study, 77 J. CRIM. L. \& CRIMINOLOGY 931, 932-36 (1986).

${ }^{4}$ See, e.g., Geraldine Mackenzie, How Judges Sentence 13-78 (2005).

45 See, e.g., Edna Erez \& Pamela Tontodonato, The Effect of Victim Participation in Sentencing on Sentencing Outcome, 28 CRIMINOLOGY 451, 453 (1990).

${ }^{46}$ Louis F. Oberdorfer, Mandatory Sentencing: One Judge's Perspective, 40 АM. CRIM. L. REV. 11, 16 (2003).

${ }^{4}$ See William W. Berry III, The Mandate of Miller, 51 AM. CRIM. L. REV. 327, 339, 345 (2014); John S. Martin, Jr., Why Mandatory Minimums Make No Sense, 18 NotRE DAME J.L. ETHICS \& PUB. POL'Y 311, 312-13 (2004).

48 Stephen J. Schulhofer, Rethinking Mandatory Minimums, 28 WAKE FOREST L. REV. 199, 210-11 (1993).

${ }^{49}$ See Berry, supra note 47, at 329-30. 
such sentences..$^{50}$ To the contrary, the political support on both sides of the political spectrum for LWOP suggests that status quo will not change anytime soon. ${ }^{51}$

\section{B. Explaining the Rise of $L W O P$}

\section{Statutory History}

Prior to the late 1980s, LWOP sentences were not common in the United States. In 1992, a mere 12,000 offenders were serving LWOP sentences in America. $^{52}$ This number grew to 33,000 by 2003 , and to over 41,000 by 2008.53 As indicated above, three distinct phenomena explain this rise in LWOP sentences: (1) the abolition of parole and embrace of truth-insentencing laws, (2) the increase in mandatory sentences, and (3) the increasing view of LWOP as the alternative to capital sentences. ${ }^{54}$

Broadly, this rise is part and parcel of the shift in American criminal justice policy from the penal welfarism model of the 1960s and early 1970s to the penal populism model of the 1980s and 1990s ${ }^{55}$ With the rise of crime in the United States in the 1970s and 1980s, the penal model shifted from one focused on rehabilitation to one enraptured with retribution and incapacitation. ${ }^{56}$

The rhetoric and ensuing actions of politicians in the tough-on-crime era of penal populism made several fundamental changes to criminal sentencing processes that resulted in an explosion of inmates, including the expansion of LWOP. ${ }^{57}$ At the forefront of these changes were the abolition of parole and increase in truth-in-sentencing statutes, and the widespread adoption of mandatory minimum sentences. ${ }^{58}$

Indeed, one significant step in the rise of LWOP sentences was Congress' adoption of the Sentencing Reform Act of $1984 .{ }^{59}$ This Act, which went into effect in 1987, abolished parole for those sentenced under the newly adopted

50 See generally Life Without Parole: AmericA's New DeAth PenAlty? (Charles J. Ogletree, Jr. \& Austin Sarat eds., 2012). But see O'Hear, supra note 2, at 1.

51 See O'Hear, supra note 2, at 3.

52 See NELLIS \& KING, supra note 18 , at 10.

53 See id.

54 See supra Part I.

55 See, e.g., David Garland, The Culture of Control: Crime AND Social Order IN CONTEMPORARY SOCIETY 27-74 (2001).

${ }^{56}$ Id.; Tim Newburn \& Trevor Jones, Symbolic Politics and Penal Populism: The Long Shadow of Willie Horton, 1 CRIME Media Culture 72, 73 (2005).

${ }^{57}$ Garland, supra note 55, at 53-74; Mike Hough, Populism and Punitive Penal Policy, 49 CRIM. Justice MATters 4, 4 (2002).

58 GARLAND, supra note 55, at 53-74.

${ }^{59}$ Sentencing Reform Act of 1984, Pub. L. No. 98-473, 98 Stat. 1987 (codified as amended in scattered sections of 18 and 28 U.S.C.). 
federal sentencing guidelines. ${ }^{60}$ Less than a decade earlier, Congress had reduced parole eligibility for federal life sentences to ten years. ${ }^{61}$ Under the Act, however, all federal life sentences imposed beginning in 1976 became LWOP sentences.

But it was not just the federal government that followed this path. By 2000 , sixteen states had abolished discretionary parole for all crimes. ${ }^{62}$ In addition, twenty-nine states and the District of Columbia had adopted the federal truth-in-sentencing standard that required violent offenders to serve eighty-five percent of their sentences. ${ }^{63}$

The consequence in many states of these reforms was to change the definition of a life sentence. ${ }^{64}$ Prior to the move towards penal populism, a life sentence often meant that an offender served between fifteen and twenty years with the possibility of parole after that time. ${ }^{65}$ By abolishing parole, states turned these sentences into LWOP sentences. ${ }^{66}$

Certainly, it was the intention of the politicians to prevent dangerous offenders from receiving parole and committing additional offenses, particularly violent ones. ${ }^{67}$ To the extent that the narrative of the penal populists was true and parole board leniency filled society with dangerous offenders who were contributing to increased crime rates, these reforms directly addressed that issue. ${ }^{68}$ The reality, though, was a shift from one extreme to another, moving from a perceived leniency to a punitive harshness exceeding that which the world had ever seen. ${ }^{69}$

Nowhere did legislatures systematically consider whether individual crimes deserved LWOP sentences. ${ }^{70}$ Unlike the death penalty statutes, which were a product of careful legislative determination after Furman v. Georgia,

${ }^{60}$ Id.; William W. Berry III, Discretion Without Guidance: The Need to Give Meaning to $\$ 3553$ After Booker and Its Progeny, 40 CoNN. L. REV. 631, 640 (2008).

61 See Lerner, supra note 7, at 1115; Harvard Note, supra note 5, at 1840.

${ }^{6}$ See HuGHES ET AL., supra note 27, at 1.

$63 \mathrm{See} i \mathrm{~d}$. at 3 . Violent offenses, as defined by the Federal Bureau of Investigation's Uniform Crime Reports, include murder, non-negligent manslaughter, rape, robbery, and aggravated assault. Id.

${ }^{64}$ See Nellis, supra note 18, at 27-28; Harvard Note, supra note 5, at 1841-43.

65 See Nellis \& KING, supra note 18 , at 1-2.

66 Id.

${ }^{67}$ Peter J. Benekos, Public Policy and Sentencing Reform: The Politics of Corrections, 56 Fed. PROB. 4, 6 (1992); see also ANDREW VON HIRSCH \& KATHLEEN J. Hanrahan, The Question of Parole: Retention, Reform, or Abolition? 13-24 (1979).

${ }^{68}$ Robert P. Crouch, Jr., Uncertain Guideposts on the Road to Criminal Justice Reform: Parole Abolition and Truth-in-Sentencing, 2 VA. J. Soc. POL'Y \& L. 419, 422-23 (1995).

69 Thomas B. Marvell \& Carlisle E. Moody, Determinate Sentencing and Abolishing Parole: The Long-Term Impacts on Prison and Crime, 34 CRIMINOLOGY 107, 122-23 (1996).

${ }^{70}$ See Crouch, supra note 68 , at 420-21. 
the life statutes that remained after the abolition of parole in many states did not receive legislative attention. ${ }^{71}$

\section{LWOP and the Death Penalty}

Another reason for the proliferation of LWOP sentences in the United States has been the use of LWOP as an alternative to the death penalty. With dangerousness being a central consideration in capital cases for two decades after Furman, the sentencing decision in capital cases became one between death and possible parole after fifteen years. ${ }^{72}$

When LWOP became a more widespread sentencing option in the late 1990s, the sentencing calculus in capital cases changed. ${ }^{73}$ Instead of choosing between a death sentence and fifteen years with possible parole, the choice became between death and LWOP - another kind of death sentence. ${ }^{74}$ As a result, death penalty sentences steadily decreased over the next decade. ${ }^{75}$ With an LWOP sentence, juries began to realize that the offender would never live outside of state custody. ${ }^{76}$ Whether the death of the offender in prison was by lethal injection or by natural causes became less important. ${ }^{77}$ LWOP sentences thus increasingly allowed jurors skeptical of the death penalty to have a clean conscience in not having chosen execution. ${ }^{78}$

As David Garland has explained in his recent book, Peculiar Institution, the culture surrounding the use of capital punishment in the United States has shifted drastically over the last fifty years. ${ }^{79}$ Once a public exhibition which citizens travelled from miles around to witness, modern executions have become secret, medical procedures that occur in the middle of the night away from public sight. ${ }^{80}$ Garland argues that this shift reflects the growing queasiness and uncertainty Americans have about the idea of the state

${ }^{71}$ Corinna Barrett Lain, Furman Fundamentals, 82 WASH. L. REV. 1, 47-48 (2007). See generally Furman v. Georgia, 408 U.S. 238 (1972).

72 Berry, supra note 42, at 893; John H. Blume et al., Future Dangerousness in Capital Cases: Always “At Issue,” 86 CoRnell L. REV. 397, 398 (2001).

${ }^{73}$ William W. Berry III, Ending the Death Lottery: A Case Study of Ohio's Broken Proportionality Review, 76 OHIO ST. L.J. 67, 80 (2015); Harvard Note, supra note 5, at 1850.

${ }^{74}$ Berry, supra note 73 , at $80-81$.

75 See Harvard Note, supra note 5, at 1845.

76 See id. at 1844-45. But see Theodore Eisenberg et al., The Deadly Paradox of Capital Jurors, 74 S. CAL. L. REV. 371, 373 (2001) (arguing that initially jurors had trouble believing LWOP sentences meant no possibility of release).

77 See David Garland, Peculiar Institution: America's Death Penalty in an Age of Abolition 52 (2010).

${ }^{78}$ Id.; Michael L. Radelet, More Trends Toward Moratoria on Executions, 33 ConN. L. REV. 845, 855 (2001).

${ }^{79}$ See GARLAND, supra note 77, at 52.

${ }^{80} \mathrm{Id}$; Patricia Ewick, Punishment, Power, and Justice, in 1 JUSTICE AND POWER IN Sociolegal Studies 36, 45, 49 (Bryant G. Garth \& Austin Sarat eds., 1998). 
executing criminals. ${ }^{81}$ Despite the many who advocate for executions, most still prefer the actual execution to remain out of sight and out of mind. ${ }^{82}$

Public opinion polls reflect this reality. Recent polls demonstrate that while around sixty percent of Americans favor capital punishment, this number drops to below fifty percent when LWOP is also an option. ${ }^{83}$ The concern, then, seems to be keeping society safe from dangerous offenders as opposed to making spectacles of punishing them by using the death penalty. ${ }^{84}$

The popularity of LWOP as a sentencing alternative to the death penalty has grown such that in some jurisdictions, it is the only sentencing alternative to death for aggravated murderers. ${ }^{85}$ Such sentencing schemes provide the community the security that certain offenders will never pose a danger to the community again.

In other jurisdictions, prosecutors use the death penalty as a plea bargaining tool to secure LWOP sentences. ${ }^{86}$ Such an approach allows prosecutors to appear tough on crime while avoiding the difficulty and expense of a capital trial, much less years of capital appeals. ${ }^{87}$

\section{LWOP and Parole Abolition}

In addition to the death penalty, the decision of many states and the federal government to abolish parole has contributed to the dramatic increase of LWOP sentences over the past three decades. Prior to the adoption of LWOP sentences, a life sentence in most states meant that the offender had a possibility of parole after fifteen years. ${ }^{88}$ And in most states, that meant a likelihood of release after fifteen years, or maybe a few years after that ${ }^{89}$ In many states, life sentences seldom resulted in an actual life sentence..$^{90}$ From

\footnotetext{
${ }^{81}$ See GARLAND, supra note 77, at 54, 60.

82 See generally John D. Bessler, DeAth in the DARK: Midnight EXECUTIONS IN AMERICA (1997).

${ }^{83}$ See Jeffrey M. Jones, Americans' Support for Death Penalty Stable, GALLuP (Oct. 23, 2014), http://www.gallup.com/poll/178790/americans-support-death-penaltystable.aspx [http://perma.cc/JZH3-J5AC].

${ }^{84}$ See Berry, supra note 42, at 893-94; Blume et al., supra note 72, at 397-99.

${ }^{85}$ See Ashley Nellis, Tinkering with Life: A Look at the Inappropriateness of Life Without Parole as an Alternative to the Death Penalty, 67 U. MIAMI L. REV. 439, 446 (2013).

${ }^{86}$ See Kent S. Scheidegger, The Death Penalty and Plea Bargaining to Life Sentences 13 (Criminal Justice Legal Found., Working Paper No. 09-01, 2009), http://www.cjlf.org/ publications/papers/wpaper09-01.pdf [http://perma.cc/68AD-S8Y6].

${ }^{87}$ This is not an insignificant benefit as the costs of capital trials and appeals far outweigh the costs of life imprisonment. $I d$.

${ }^{88}$ See Harvard Note, supra note 5, at 1840 (citing Peter B. Hoffman, History of the Federal Parole System: Part 1 (1910-1972), 61 Fed. Probation 23, 24 (1997)).

${ }^{89}$ Id.; see also Andrew M. Hladio \& Robert J. Taylor, Parole, Probation and Due Process, 70 PA. B. Ass'N Q. 168, 169-70 (1999).

90 MAUER ET AL., supra note 2, at 1 n.3, 4.
} 
the perspective of the state legislatures, then, the life sentences were often the maximum sentence as part of a broad sentencing range.

With the abandonment of parole in many jurisdictions, including the federal government, the fifteen- to twenty-year life sentence became a deathin-custody sentence. ${ }^{91}$ States did not, for the most part, re-examine their statutes to assess whether such sentences were appropriate for crimes. ${ }^{92}$ Rather, the sentences just became a different kind of sentence..$^{93}$

As a result, the abolition of parole was a contributing factor to the steady increase in LWOP sentences. This has been most true in Florida, which has seen a proliferation of juvenile LWOP sentences among offenders that previously might have had the opportunity for parole after fifteen years, but for the abolition of parole. ${ }^{94}$

\section{LWOP, Penal Populism, and Mandatory Sentences}

The abolition of parole is part and parcel of a broader movement from penal welfarism to penal populism over the last few decades of the twentieth century. ${ }^{95}$ In the 1960 s and 1970 s, the primary concern for prisons was the rehabilitation of prisoners. ${ }^{96}$ Dubbed correctional institutions, these facilities sought to correct the character deficiency of the offender such that the offender could one day rejoin society. ${ }^{97}$

As explained above, the high crime rates of the 1970s set the stage for the penal populism movement of the 1980s and 1990s, in which retribution and incapacitation replaced rehabilitation as the dominant justification for imprisonment. ${ }^{98}$ The culture sought to control offenders through harsh punishments that likewise served to protect society from dangerous individuals. ${ }^{99}$

Politicians of both parties adopted this "tough on crime" mantra. ${ }^{100}$ As a result, a proliferation of new statutes increased criminal penalties for many crimes. ${ }^{101}$ The federal government, for instance, added a recidivist premium with the adoption of the sentencing guidelines, making LWOP sentences more

${ }^{91}$ Id. at 1 n. 3 .

${ }^{9}$ See generally Frederick A. Hussey \& Stephen P. Lagoy, The Determinate Sentence and Its Impact on Parole, 19 CRIM. L. BULL. 101, 104 (1983).

93 MAUER ET AL., supra note 2, at 5.

94 Graham v. Florida, 560 U.S. 48, 64 (2010).

95 GARLAND, supra note 55, at 53-55.

$96 \mathrm{Id}$. at 34 .

${ }^{97} \mathrm{Id}$. at $34-35$

$98 \mathrm{Id}$. at 62.

${ }^{99} \mathrm{Id}$.

${ }^{100}$ Id. at 13; Marc Mauer, Why Are Tough on Crime Policies So Popular?, 11 STAN. L. \& POL'Y REV. 9, 10-11 (1999).

${ }^{101}$ Michelle AleXANDER, The New Jim Crow: Mass InCARCERATION IN THE Age OF COlORBLINDNESS 59 (2010); see MARC MAUER, RACE TO INCARCERATE 56-78 (1999). 
likely for repeat offenders, particularly in drug cases. ${ }^{102}$ Similarly, states like California adopted three strikes laws that imposed life sentences for offenders with three felony convictions. ${ }^{103}$

The widespread adoption of mandatory minimum sentences also contributed to the increase in LWOP sentences. ${ }^{104}$ On the federal level, the recidivist premiums, particularly in drug cases, created many situations where the mandatory minimum penalty became an LWOP sentence. ${ }^{105}$

On the state level, LWOP can be the product of a mandatory sentence in several ways. First, LWOP sentences are the mandatory minimum sentence for offenders convicted of aggravated murder. ${ }^{106}$ Indeed, in twenty-seven states, LWOP is mandatory upon conviction for at least one offense. ${ }^{107}$

Second, LWOP is mandatory in other states-Alabama, California, Florida, Louisiana, South Carolina, Virginia, and Washington - for individuals convicted of serious habitual offender laws. ${ }^{108}$ Finally, in six states-Illinois, Iowa, Louisiana, Maine, Pennsylvania, and South Dakota - and the federal government, all life sentences are automatically LWOP sentences because there is no parole system. ${ }^{109}$

\section{Why LWOP Deserves Heightened Scrutiny}

Given this perfect storm of events that led to an increase in LWOP sentences, the question becomes whether such sentences deserve heightened scrutiny, and if so, why such consideration is necessary. An overview of the Court's Eighth Amendment cases demonstrates this need.

The United States Supreme Court has long held that "death is different," meaning that capital cases deserve heightened scrutiny because of the irrevocability and finality of a capital sentence. ${ }^{110}$ More recently, the Court has

102 See GARLAND, supra note 55, at 132-33.

103 See generally Franklin E. ZiMring ET AL., PUNISHMENT AND DEMOCRACY: THREE STRIKES AND YOU'RE OUT IN CALIFORNIA (2001).

${ }^{104}$ See Harvard Note, supra note 5, at 1842; see also U.S. SENTENCING COMM'N, supra note 24 , at 63 .

105 See U.S. SEntencing COMM'N, supra note 24, at 63. See generally Sentencing Reform Act of 1984, Pub. L. No. 98-473, 98 Stat. 1987 (codified as amended in scattered sections of 18 and 28 U.S.C.).

106 Nellis, supra note 18, at 27.

107 Id. at 28 .

108 Id. at 27.

109 Id. at 28 .

110 Justice Brennan's concurrence in Furman v. Georgia is apparently the origin of the Court's death-is-different capital jurisprudence. See Furman v. Georgia, 408 U.S. 238, 286 (1972) (Brennan, J., concurring) ("Death is a unique punishment in the United States."); see also Jeffrey Abramson, Death-is-Different Jurisprudence and the Role of the Capital Jury, 2 OHIO ST. J. CRIM. L. 117, 117 (2004) (discussing the Court's death-is-different jurisprudence); Carol S. Steiker \& Jordan M. Steiker, Sober Second Thoughts: Reflections 
held that "kids are different" and accorded similar scrutiny in cases involving juvenile LWOP sentences. ${ }^{111}$ For all other criminal cases, including adult LWOP sentences, the Court has applied its "gross disproportionality" standard, which accords almost complete deference to state and federal sentencing decisions. ${ }^{112}$

As I have argued elsewhere, though, adult LWOP sentences likewise deserve some level of heightened scrutiny. ${ }^{113}$ In Graham v. Florida, the Court recognized the similarity of the death penalty and LWOP, explaining:

As for the punishment, life without parole is "the second most severe penalty permitted by law." It is true that a death sentence is "unique in its severity and irrevocability," yet life without parole sentences share some characteristics with death sentences that are shared by no other sentences. The State does not execute the offender sentenced to life without parole, but the sentence alters the offender's life by a forfeiture that is irrevocable. It deprives the convict of the most basic liberties without giving hope of restoration . . . .114

While perhaps not as "different" as the death penalty, life without parole is its own kind of different, as it constitutes a decision to sentence an offender to death in prison. ${ }^{115}$ Justice Kennedy has explained that LWOP, like the death penalty, "alters the offender's life by a forfeiture that is irrevocable." $116 \mathrm{In}$ essence, an LWOP sentence is a death sentence without an execution date. ${ }^{117}$

As indicated, a sentence of LWOP is a decision that the life of the offender is irredeemable - and thus, no one will revisit the decision to keep the offender in custody until his death. ${ }^{118}$ LWOP sentences and capital sentences thus share

on Two Decades of Constitutional Regulation of Capital Punishment, 109 HARV. L. REV. 355, 370 (1995) (crediting Justice Brennan as the originator of this line of argument).

111 Miller v. Alabama, 132 S. Ct. 2455, 2475 (2012).

112 See Harmelin v. Michigan, 501 U.S. 957, 959 (1991).

113 Berry, supra note 47, at 329-30.

${ }^{114}$ Graham v. Florida, 560 U.S. 48, 69-70 (2010) (citations omitted) (first quoting Harmelin, 501 U.S. at 1001 (Kennedy, J. concurring in part and concurring in judgment); and then quoting Gregg v. Georgia, 421 U.S. 153, 187 (1976) (joint opinion of Stewart, Powell, and Stevens, JJ.))

115 See, e.g., Naovarath v. State, 779 P.2d 944, 944 (Nev. 1989) ("[Life without parole] means denial of hope; it means that good behavior and character improvement are immaterial; it means that whatever the future might hold in store for the mind and spirit of [the convict], he will remain in prison for the rest of his days."); William W. Berry III, More Different than Life, Less Different than Death, 71 OHIо ST. L.J. 1109, 1109 (2010).

116 Graham, 560 U.S. at 69.

117 See, e.g., Appleton \& Grøver, supra note 11, at 611.

118 See Miller v. Alabama, 132 S. Ct. 2455, 2469 (2012) (citing Graham, 560 U.S. at 69); see, e.g., Appleton \& Grøver, supra note 11, at 610; Robert Blecker, Less than We Might: Meditations on Life in Prison Without Parole, 23 FeD. SENT'G REP. 10, 12 (2010) (arguing for abolishing life without parole); Nellis, supra note 18, at 28; O'Hear, supra 
the reality that one has no legitimate hope of escaping confinement prior to death. ${ }^{119}$

Further, in certain ways, a sentence of life without parole can be worse than a sentence of death. ${ }^{120}$ A death sentence has an end date, which for some may be less traumatic than imprisonment until one dies of natural causes. ${ }^{121}$ To the extent that living in prison constitutes suffering, life without parole allows for greater suffering, or at least a longer time for suffering. ${ }^{122}$ As mentioned above, one example of the desirability of ending one's time in prison as soon as possible is the prevalence of "volunteers" in capital casesindividuals who choose to waive their appeals and accelerate their execution date. ${ }^{123}$

Practically, a sentence of life without parole can also be worse than a death sentence in that the possibility of reversal is dramatically less. ${ }^{124}$ Because courts view death as different, capital cases receive far more extensive and careful review than LWOP sentences. ${ }^{125}$ The reversal rate in LWOP cases is

note 2 , at 5 (describing life without parole as a "civil death"); Alice Ristroph, Hope, Imprisonment, and the Constitution, 23 FED. SENT'G REP. 75, 75 (2010).

119 See Appleton \& Grøver, supra note 11, at 610.

${ }^{120}$ See Logan, supra note 14, at 712 n.143 (citing cases where inmates preferred death sentences to terms of life in prison); see also White, supra note 14, at 853-61.

121 See Appleton \& Grøver, supra note 11, at 605-06.

122 See, e.g., Adam Liptak, Serving Life, with No Chance of Redemption, N.Y. TIMES (Oct. 5, 2005), http://www.nytimes.com/2005/10/05/us/serving-life-with-no-chance-ofredemption.html [http://perma.cc/V7RA-CHJZ] ("I wish I still had that death sentence. .. . Really, death has never been my fear. What do people believe? That being alive in prison is a good life? This is slavery." (quoting prisoner Randy Arroyo commenting on his converted sentence, who had been sentenced to death as a juvenile but was spared by the Roper decision)).

${ }^{123}$ See, e.g., John H. Blume, Killing the Willing: "Volunteers," Suicide and Competency, 103 MiCH. L. REV. 939, 940 n.5 (2005); Anthony J. Casey, Maintaining the Integrity of Death: An Argument for Restricting a Defendant's Right to Volunteer for Execution at Certain Stages in Capital Proceedings, 30 AM. J. CRIM. L. 75, 76 nn.1-2 (2002); see also Chandler, supra note 1, at 1902; G. Richard Strafer, Volunteering for Execution: Competency, Voluntariness and the Propriety of Third Party Intervention, $74 \mathrm{~J}$. CRIM. L. \& CRIMINOLOGY 860, 860-61 (1983).

${ }^{124}$ See, e.g., Alex Kozinski \& Stephen Bright, Debate, The Modern View of Capital Punishment, 34 AM. CRIM. L. REV. 1353, 1360-61 (1997) (quoting Judge Alex Kozinski's view that innocent defendants are better off being charged with a capital crime in California because they will get "a whole panoply of rights of appeal and review that you don't get in other cases"); Patrick McIlheran, Illinois Re-Examines Life Sentences, J. SENTINEL (Oct. 25, 2006), http://www.jsonline.com/news/opinion/29214734.html [http:// perma.cc/T7DX-LG43] ("[T]he safeguards that states build into capital cases - the things that make the death penalty so costly - make it less likely an innocent man will be executed than simply imprisoned wrongly.").

125 Kozinski \& Bright, supra note 124, at 1360-61; see also Harvard Note, supra note 5, at 1853 ("Unlike death sentences, which merit a heightened level of appellate review, life-without-parole sentences receive no special consideration from appellate tribunals ...."). 
far less than in capital cases, and even where error is present, courts are more likely to consider it harmless in a LWOP case than in a capital case. ${ }^{126}$

In addition to the differentness of LWOP, the current process by which states sentence offenders to LWOP fails to ask the proper questions. As indicated above, LWOP sentences indicate a decision by the state that the offender deserves to die in prison because either the offender's conduct merits such a punishment, because society has determined that the life of the offender is irredeemable, or both, with no hope of ever rejoining society.

From a retributive perspective, then, the Court ought to ask whether the harm caused by criminal conduct of the offender and culpability of the offender warrant LWOP. Specifically, the retributive question is whether the just deserts of the offender must be permanent banishment from society and death in prison.

From a utilitarian perspective, similarly, the question is whether the offender is irredeemable, whether the life of the offender can ever have any value to society. In sentencing an offender to LWOP, then, a court or jury should determine that the offender is someone who can never rejoin society.

In practice, however, neither the determination of whether the offender deserves banishment nor the determination of whether the offender is irredeemable enters into the calculus of the judge or jury at sentencing. This is because no separate sentencing procedure exists to address either of those questions. ${ }^{127}$

In capital cases, for instance, the decision to sentence an offender to LWOP is in most cases, simply an alternative to a death sentence. ${ }^{128}$ Many states make LWOP a mandatory sentencing alternative, such that a jury decision not to award a death sentence in a capital murder case automatically results in an LWOP sentence. ${ }^{129}$ Even when capital juries have the option of electing to give an aggravated murderer a life with parole sentence, there is no required finding necessary prior to the imposition of LWOP.

As the Court's death penalty jurisprudence makes clear, the need for consideration of the individualized characteristics of the offender and the crime are paramount to the decision to sentence an individual to death. ${ }^{130}$ The imposition of an LWOP sentence, its own type of death penalty, should warrant the same kind of scrutiny. ${ }^{131}$

${ }^{126}$ Harvard Note, supra note 5, at 1853 . The estimated rate of reversal for non-capital sentences is approximately seven percent, while according to one study the rate of reversal of a capital sentence is seventy-three percent at the federal court of appeals level. $I d$.

127 Berry, supra note 47, at 345-46.

128 See Harvard Note, supra note 5, at 1838.

129 See State Adoption of LWOP, supra note 6.

${ }^{130}$ Lockett v. Ohio, 438 U.S. 586, 602-03 (1978); Woodson v. North Carolina, 428 U.S. 280, 304 (1976); Berry, supra note 47, at 345-46.

${ }^{131}$ Berry, supra note 115 , at 1143-46. 
Most decisions to impose LWOP sentences, however, lack an explicit individualized sentencing determination. ${ }^{132}$ This means that the judge or jury does not carefully consider whether the sentenced individual deserves permanent banishment from society, is irredeemable as a person, or both. ${ }^{133}$ Mandatory LWOP sentences create much of this problem, but capital cases that do not provide any other alternative to a death sentence than LWOP also contribute to the lack of individualized consideration of such offenders. ${ }^{134}$

Lumping an offender's case with a group of legislatively defined "similar" cases, whether as a mandatory or discretionary sentence, cheapens the humanity of the offender when the stakes are so high. ${ }^{135}$ If the state decides to banish an offender to die in prison, it should be a careful decision considering the individual circumstances of the offender, not the result of careless categorizations made at an earlier date.

\section{THE ARGUMENT FOR LWOP ABOLITION}

In light of the unfortunate and unprecedented rise of LWOP in the United States and its many negative consequences, the need for abolition of LWOP becomes apparent. Specifically, the United States should ban LWOP sentences because (1) LWOP sentences violate human rights, (2) LWOP sentences are cruel and unusual punishments, and (3) reasonable sentencing alternatives to LWOP exist.

\section{A. LWOP Sentences Violate Human Rights}

In many ways, human rights law rests on the concept of human dignity. ${ }^{136}$ In the preamble to the Charter of the United Nations, for instance, the second paragraph equates human rights to human dignity, explaining the charter's goal "to reaffirm faith in fundamental human rights, in the dignity and worth of the human person, in the equal rights of men and women and of nations large and small." 137 Similarly, Article 1 of the Universal Declaration of Human Rights provides: "All human beings are born free and equal in dignity and rights." 138 Such provisions are common in international and national

132 See Harvard Note, supra note 5, at 1853.

133 Berry, supra note 47, at 345.

${ }^{134}$ Id.

135 See Miller v. Alabama, 132 S. Ct. 2455, 2474-75 (2012); Graham v. Florida, 560 U.S. 48, 77 (2010); Berry, supra note 47, at 345.

${ }^{136}$ See generally The CONCEPT OF Human Dignity IN Human Rights Discourse (David Kretzmer \& Eckart Klein eds., 2002); Oscar Schachter, Editorial Comment, Human Dignity as a Normative Concept, 77 AM. J. INT'L L. 848 (1983).

137 U.N. Charter pmbl.

138 G.A. Res. 217 (III) A, Universal Declaration of Human Rights art. 1 (Dec. 10, 1948), http://www.ohchr.org/EN/UDHR/Pages/Language.aspx?LangID=eng [http://perma.cc/ 4475-7B72]. 
documents outlining human rights. ${ }^{139}$ In the American constitutional context, the Supreme Court has explained that the Eighth Amendment's prohibition against "cruel and unusual" punishments draws its meaning from the "dignity of man." 140

Despite the United States Supreme Court's decisions to the contrary, ${ }^{141}$ LWOP sentences impinge on the human dignity of the offender. ${ }^{142}$ Such a sentence is a one-time decision that the offender deserves a death-in-custody sentence, a complete condemnation of the offender as a person. ${ }^{143}$ This is problematic for two important reasons. It is impossible to say, as a one-time judgment, that the length of the sentence satisfies the demands of proportionality, particularly as societal assessments of offense gravity and offender blameworthiness can shift over the course of a generation. ${ }^{144}$ Second, a one-time sentencing decision does not allow for changes in the offender's rehabilitation or dangerousness over time. ${ }^{145}$

Nonetheless for some crimes, society and family members of victims might argue that the criminal conduct of the offender deserves just that-

${ }^{139}$ See, e.g., International Covenant on Civil and Political Rights art. 10(1), adopted Dec. 19, 1966, 999 U.N.T.S. 172 (explaining that "[a]11 persons deprived of their liberty shall be treated with humanity and with respect for the inherent dignity of the human person"); see also American Convention on Human Rights art. 5, Nov. 22, 1969, 1144 U.N.T.S. 144 (similar provision); $c f$. International Covenant on Economic, Social, and Cultural Rights art. 13, adopted Dec. 16, 1966, 993 U.N.T.S. 4 (providing that "education shall be directed to the full development of the human personality and the sense of its dignity"); Conference on Security and Co-Operation in Europe: Final Act, Aug. 1, 1975, 14 I.L.M. 1292, 1295 (indicating that states will promote human rights and freedoms, "all of which derive from the inherent dignity of the human person").

140 Trop v. Dulles, 356 U.S. 86, 100 (1958) ("The basic concept underlying the Eighth Amendment is nothing less than the dignity of man."); Weems v. United States, 217 U.S. 349, 366 (1910) (expanding its interpretation of the cruel and unusual punishment clause by stating, "No circumstance of degradation is omitted [from Eighth Amendment scrutiny]. It may be that even the cruelty of pain is not omitted."); William W. Berry III, Following the Yellow Brick Road of Evolving Standards of Decency: The Ironic Consequences of "Death-is-Different” Jurisprudence, 28 PACE L. REV. 15, 17-18 (2007); Meghan J. Ryan, Judging Cruelty, 44 U.C. DAVIS L. REV. 81, 100-02 (2010).

${ }^{141}$ See, e.g., Ewing v. California, 538 U.S. 11, 30-31 (2003); Harmelin v. Michigan, 501 U.S. 957, 957 (1991).

142 See, e.g., Appelton \& Grøver, supra note 11, at 605-06; Nellis, supra note 85, at 456.

${ }^{143}$ Nellis, supra note 85, at 457; see Ashley Kloepfer, Denial of Hope: Sentencing Children to Life in Prison Without the Possibility of Parole, 26 J. C.R. \& ECON. DEV. 387, 387 (2012).

144 Model Penal Code: Sentencing $\S 305.6 \mathrm{cmt}$. b (AM. Law Inst., Tentative Draft No. 2, 2011). Indeed, the norms and priorities of the criminal law have shifted often in the United States. See Lawrence M. Friedman, Crime and Punishment in American History 6-8 (1993). See generally DAVID F. Musto, THE AMERICAN DiseAse: ORIGINS OF NARCotic Control (Oxford Univ. Press 3d ed. 1999) (1973); SAMUEl WALKER, Popular JustiCE: A History OF AMERICAN CRIMINAL JustiCE (2d ed. 1998).

145 Model Penal Code: Sentencing $§ 305.6 \mathrm{cmt}$. b. 
forfeiture of his humanity-as the punishment commensurate to the seriousness of the offender's transgression. ${ }^{146}$ From a human rights perspective, the saliency of this argument tracks the debate about the morality of capital punishment. ${ }^{147}$ On the one hand, many victims' rights advocates argue that premeditated murder demands that the state take the life of the offender, as the act of taking the life of another without adequate justification forfeits one's right to live. ${ }^{148}$ The answer to that claim is that the state must engage in the prohibited act-intentional murder-in order to punish the offender. ${ }^{149}$ In other words, two wrongs do not make a right, and modern conceptions of human rights counsel against this brutal response to brutal criminal offenses. ${ }^{150}$

LWOP sentences are no different. Locking an offender in a cage and essentially throwing away the key-condemning them to die in state custody - is simply another version of a death sentence. ${ }^{151}$ It begs the question of whether the actions of an offender can justify the state taking away the humanity of a person. ${ }^{152}$

From a utilitarian perspective, LWOP sentences communicate that the offender is irredeemable as a person-that there is no hope for their ability to ever rejoin society. ${ }^{153}$ Such a determination is dehumanizing - there is no hope for the offender's life - and as such, the state has condemned the offender to die in a small cage. ${ }^{154}$

${ }^{146}$ Marilyn Peterson Armour \& Mark S. Umbreit, Exploring "Closure" and the Ultimate Penal Sanction for Survivors of Homicide Victims, 19 FED. SENT'G REP. 105, 105 (2006); Marilyn Peterson Armour \& Mark S. Umbreit, The Ultimate Penal Sanction and "Closure" for Survivors of Homicide Victims, 91 MARQ. L. REV. 381, 384 (2007).

${ }^{147}$ See generally StUART BANNER, THE DEATH PENALty: AN AMERICAN History (2002); Hugo Adam Bedau, Death is Different: Studies in the Morality, LaW, AND Politics of Capital Punishment (1987); Walter Berns, For Capital Punishment: Crime and the Morality of the Death Penalty (1979); Austin Sarat, When the State Kills: CAPITAl Punishment AND the AmERICAN CONDITION (2001); TOM Sorell, MORAL THEORY AND CAPITAL PUNISHMENT (1987).

148 See, e.g., ERnest VAn den HaAg \& John P. Conrad, The Death Penalty: A DEBATE 247 (1983).

${ }^{149}$ See Furman v. Georgia, 408 U.S. 238, 333-42 (1972) (Marshall, J., concurring); SARAT, supra note 147 , at 12.

150 See generally Furman, 408 U.S. at 370-71 (Marshall, J., concurring); RoGER HoOD \& Carolyn hoyle, The Death Penalty: A Worldwide Perspective (5th ed. 2015); Council Common Guidelines on Death Penalty (EU) No. 8416/13 Annex of 12 Apr. 2013, at 5, http://data.consilium.europa.eu/doc/document/ST-8416-2013-INIT/en/pdf [http://perma.cc/ 8QE8-56XL].

151 See generally STEVEnSON, supra note 2; Berry, supra note 47, at 341.

152 See Dan Markel, State, Be Not Proud: A Retributivist Defense of the Commutation of Death Row and the Abolition of the Death Penalty, 40 HARV. C.R.-C.L. L. REV. 407, 415, 429 (2005).

153 O'Hear, supra note 2, at 2; Ristroph, supra note 118, at 75-76.

154 Appleton \& Grøver, supra note 11, at 605-06; O’Hear, supra note 2, at 2. 
Condemnation to die in prison compromises the dignity of the offender, not just by foreclosing the opportunity to ever leave state custody, but also by eliminating any hope of rejoining society. LWOP sentences, then, are an affront to human dignity because they are life without hope sentences.

The mental consequences of knowing one will never live outside of prison, and that one will remain isolated in prison until death by natural causes can be significant. ${ }^{155}$ The LWOP sentence often imposes its own unique form of psychological torture on offenders. ${ }^{156}$

The physical and emotional reality of LWOP sentences-rooted in their hopelessness - rests at the heart of the human rights problem with such sentences. ${ }^{157}$ Studies have demonstrated these consequences, suggesting that in many ways these sentences can amount to a form of torture. ${ }^{158}$

Keeping an offender in prison until they die might not in itself violate human rights. Rather, it is the decision to condemn an individual to such a fate, and to decide to never revisit that decision. ${ }^{159}$

This second aspect - and perhaps hubris — of deciding at sentencing that an offender will never be suitable to rejoin society, deserves such a fate, or both-compromises the offender's human rights. ${ }^{160}$ As one cannot know the future, depriving an offender of the opportunity to repent and reform his character violates his human rights. ${ }^{161}$ Certainly, some offenders may not ever deserve to leave state custody, but the possibility for change counsels against making that determination a one-time decision, particularly when it occurs in the shadow of the crime the offender committed. ${ }^{162}$

The human rights of the offender demand a second look, ${ }^{163}$ and maybe a third one, of the decision that the offender is to die in prison. ${ }^{164}$ In many, perhaps most cases, such offenders will remain imprisoned. ${ }^{165}$ The possibility of release, however small, provides the offender with some ray of hope and a

155 Bruce Ledewitz \& Scott Staples, No Punishment Without Cruelty, 4 GEO. MASON U. C.R. L.J. 41, 46 (1993); Michael Meltsner, The Dilemmas of Excessive Sentencing: Death May Be Different but How Different?, 7 NE. U. L.J. 5, 9-10 (2015).

156 Margaret E. Leigey, The Forgotten Men: Serving a Life Without Parole Sentence 60 (2015); LeOn Shaskolsky Sheleff, Ultimate Penalties: Capital PUNISHMENT, LIFE IMPRISONMENT, PHYSICAL TORTURE 56 (1987).

157 Ristroph, supra note 118 , at 76.

158 SHELEF, supra note 156 , at 56.

${ }^{159}$ Berry, supra note 47, at 341-42; Nellis, supra note 85, at 449-51.

160 Vinter v. United Kingdom, 2013-III Eur. Ct. H.R. 317, 349.

${ }^{161}$ Id.; see Berry, supra note 47, at 348.

162 Appleton \& Grøver, supra note 11, at 611.

163 The concept of a "second look" is not a new one, although scholars have not argued for using it as a basis for abolishing LWOP. See, e.g., Richard F. Frase, Second Look Provisions in the Proposed Model Penal Code Revisions, 21 FED. SENT'G REP. 194, 194 (2009).

164 Model Penal Code: Sentencing $§ 305.6$ (Am. Law Inst., Tentative Draft No. 2, 2011).

${ }^{165}$ NeLLIS \& KING, supra note 18, at 6; see also HUGHES ET AL., supra note 27, at 2. 
strong incentive to pursue a path of self-reflection and change while in custody.

Without the possibility of ever leaving prison, the sentence of the offender is essentially a life-without-hope sentence. ${ }^{166}$ By contrast, if the state accords the offender some later re-examination of the life sentence, the sentence becomes a life-with-hope sentence. As proposed below, such an approach would largely remedy the human rights violation currently perpetuated by LWOP sentences throughout the United States.

Another way that LWOP sentences can violate human rights is in the disproportionate nature that many states impose them. ${ }^{167}$ Where a sentence is grossly disproportionate to the crime committed, it violates the offender's human rights. ${ }^{168}$ As South African Constitutional Court Judge Laurie Ackermann explains, "To attempt to justify any period of penal incarceration, let alone imprisonment for life ..., without inquiring into the proportionality between the offence and the period of imprisonment, is to ignore, if not to deny, that which lies at the very heart of human dignity."169

As indicated above, LWOP sentences constitute an excessive punishment for many criminal offenders. ${ }^{170}$ This is particularly true for non-violent offenders or habitual offenders, where the sentence clearly does not reflect the culpability of the offender or the harm caused by the crime. ${ }^{171}$

\section{B. LWOP Sentences Are Cruel and Unusual Punishments}

Both the statute of the European Court of Human Rights and the United States Constitution prohibit cruel and unusual punishments. The European Court of Human Rights has recently held that LWOP is a cruel and unusual punishment, although it has reconsidered this judgment. ${ }^{172}$ While the United States Supreme Court has been reluctant to reach the same conclusion, a reexamination of the Court's evolving standards of decency jurisprudence suggests that LWOP might also violate the Eighth Amendment.

166 See Ristroph, supra note 118 , at 75.

${ }^{167}$ Dirk van Zyl Smit \& Andrew Ashworth, Disproportionate Sentences as Human Rights Violations, 67 MOD. L. REV. 541, 542 (2004).

168 Id.

169 Dodo v. State 2001 (3) SA 382 (CC) para. 38 (S. Afr.), http://www.saflii.org/za/ cases/ZACC/2001/16.html [http://perma.cc/TQ4B-3Y9Y].

${ }^{170}$ Nellis, supra note 85 , at 457 .

${ }^{171}$ MAUER ET AL., supra note 2, at 20; Nellis, supra note 85, at 453.

172 Hutchinson v. United Kingdom, 2015-IV Eur. Ct. H.R. 1, 8, 11, http://hudoc. echr.coe.int/eng?i=001-150778 [http://perma.cc/3RR3-HU7W]. This case was referred to the Grand Chamber on June 1, 2015. Press Release, European Court of Human Rights, ECHR 169, Grand Chamber Panel's Decisions (June 3, 2015), http://hudoc.echr.coe.int/ eng-press? $\mathrm{i}=003-5097825-6282370$ [http://perma.cc/7J6Z-U2FK]. The case is pending before the Grand Chamber. Id. 


\section{The European Court of Human Rights}

In July 2013, the European Court of Human Rights addressed the issue of whole-life sentences in the case of Vinter v. United Kingdom. ${ }^{173}$ In that case, three British nationals challenged their LWOP sentences, arguing that the sentences constituted human rights violations. ${ }^{174}$

The provision of international human rights law that the court applied was the prohibition against cruel and unusual punishments that tracks the language of the Eighth Amendment. ${ }^{175}$ In other words, the court considered whether LWOP was a cruel and unusual punishment in violation of the human rights of the offenders. ${ }^{176}$

In Vinter, the court held that LWOP sentences constitute human rights violations. ${ }^{177}$ The court explained that the violation did not occur from the sentence itself, but instead from the decision to never revisit the sentence. ${ }^{178} \mathrm{In}$ other words, keeping a particular offender imprisoned for the rest of his life does not violate his human rights. ${ }^{179}$ Making a one-time sentencing decision, though, that he will die in prison does violate human rights. ${ }^{180}$

It is the finality of the sentencing decision and the denial of the possibility for revisiting the sentence that results in the human rights depravation. 181 From the court's perspective, this is true because it is impossible to determine that an offender will forever be irredeemable and as such, unfit to rejoin society. ${ }^{182}$ No matter the criminal act, the court found that the human rights of an offender accord him the opportunity to have his life sentence reconsidered at a later date. ${ }^{183}$

In short, sentencing an offender to life without parole violates human rights and states can remedy this only by providing for some review at a time other than sentencing. ${ }^{184}$ The court in Vinter did not specify that a particular entity perform this review, although clearly the court or a parole board could perform this function. ${ }^{185}$

173 Vinter v. United Kingdom, 2013-III Eur. Ct. H.R. 317, 319. It is worth noting that a more recent decision of the Fourth Section of the European Court of Human Rights reached the opposite decision, without mentioning Vinter. See Hutchinson, 2015-IV Eur. Ct. H.R. at 11.

174 Vinter, 2013-III Eur. Ct. H.R. at 324.

175 Id. at 339.

$176 \mathrm{Id}$.

${ }^{177} I d$. at $352-53$.

$178 \mathrm{Id}$. at 353 .

179 See id.

180 See Vinter, 2013-III Eur. Ct. H.R. at 353.

181 See id.

182 Id. at $346-47$.

183 Id.

${ }^{184}$ Id.

185 Model Penal Code: Sentencing $§ 305.6$ (AM. LAW InSt., Tentative Draft No. 2, 2011); Frase, supra note 163, at 195. 


\section{The Evolving Standards of Decency}

By contrast, the United States Supreme Court has been unwilling to declare that mandatory LWOP sentences constitute a cruel and unusual punishment, even for juveniles. ${ }^{186}$ The initial reluctance to make such a determination stems from the Court's death-penalty focused approach to the Eighth Amendment, drawing an artificial line between capital and non-capital cases such that non-capital cases never transgress this prohibition no matter how disproportionate the sentence. ${ }^{187}$ This is ironic given that the Court's first two significant Eighth Amendment decisions, Weems v. United States and Trop v. Dulles, struck down disproportionate punishments in non-capital cases. ${ }^{188}$

Recently, the Court has blurred this line in Graham v. Florida and Miller v. Alabama by declaring that juvenile LWOP sentences are cruel and unusual punishments when imposed as mandatory sentences or in non-homicide cases. ${ }^{189}$ The basis for this distinction, though, has been the unique nature of juveniles ("children are different"), not a determination that LWOP, by itself, merits further scrutiny. ${ }^{190}$

When compared to Vinter, the question becomes whether the Court's willingness to blindly defer to Congress and state legislatures with respect to LWOP sentences ignores the human rights of those sentenced to LWOP. As the Court explained in Trop v. Dulles, "[t] he basic concept underlying the Eighth Amendment is nothing less than the dignity of man."191 This sentiment suggests that the Court should revisit its prior decisions allowing LWOP sentences under the Eighth Amendment. 192

In the Supreme Court's Eighth Amendment cases, two steps inform the Court's measurement of the evolving standards of decency that define what punishments are cruel and unusual. ${ }^{193}$ First, the Court considers the objective indicia of state legislatures to determine if there is a consensus. ${ }^{194}$ Then, the

186 Miller v. Alabama, 132 S. Ct. 2455, 2460 (2012).

${ }^{187}$ Graham v. Florida, 560 U.S. 48, 106-08 (2010) (Thomas, J., dissenting); Rachel E. Barkow, The Court of Life and Death: The Two Tracks of Constitutional Sentencing Law and the Case for Uniformity, $107 \mathrm{MICH}$. L. REV. 1145, 1145 (2009) (acknowledging the Court's different treatment of capital cases); Douglas A. Berman, A Capital Waste of Time? Examining the Supreme Court's “Culture of Death," 34 OHIO N.U. L. REV. 861, 879-81 (2008).

188 Trop v. Dulles, 356 U.S. 86, 104 (1958); Weems v. United States, 217 U.S. 349, 382 (1910); William W. Berry III, Promulgating Proportionality, 46 GA. L. REV. 69, 9495 (2011).

${ }^{189}$ Miller, 132 S. Ct. at 2475; Graham, 560 U.S. at 82.

190 Miller, 132 S. Ct. at 2469.

191 Trop, 356 U.S. at 100.

192 Berry, supra note 47 , at 341-43.

193 Roper v. Simmons, 543 U.S. 551, 560-61 (2005); Trop, 356 U.S. at 100-01.

194 Coker v. Georgia, 433 U.S. 584, 596 (1977). 
Court brings its own judgment to bear, assessing whether the punishment satisfies any of the purposes of punishment. 195

As to the first inquiry, if the Court looks only to the sentencing practices of the states and the federal government, then LWOP is not a cruel and unusual punishment, as forty-nine of fifty states and the federal government allow, and in many cases mandate, LWOP sentences. ${ }^{196}$

In the past, though, the Court has also looked to worldwide practices to determine the content of the evolving standards of decency. ${ }^{197}$ If the determination of whether a punishment is cruel and unusual depends on world as opposed to domestic standards, then a different calculus emerges. ${ }^{198}$

As with the death penalty, the United States' use of LWOP places it as an outlier among civilized nations. ${ }^{199}$ International human rights law does not directly address LWOP as a sentence, but does require states to ensure that " $[\mathrm{t}]$ he penitentiary system shall comprise treatment of prisoners the essential aim of which shall be their reformation and social rehabilitation."200

The International Criminal Court's Rome Statute likewise does not allow for LWOP sentences, requiring that life sentences be reviewable after twentyfive years. ${ }^{201}$ This is despite the jurisdiction of the ICC including far worse crimes than American courts typically consider, including genocide, war crimes, and crimes against humanity. ${ }^{202}$ The number of signatories to the Rome Statute-123 nations, but not the United States - indicates a worldwide consensus against the use of LWOP sentences. ${ }^{203}$ Only thirty-eight of the world's 193 countries allow LWOP sentences. ${ }^{204}$

To be sure, the United States' use of LWOP sentences far exceeds the practice of any other Western nation. ${ }^{205}$ Among European nations, only ten allow the imposition of LWOP sentences. ${ }^{206}$ Further, European nations can

195 Id. at 598.

196 DE LA VEGA ET AL., supra note 30, at 22. Alaska is the one state that proscribes LWOP sentences. State Adoption of LWOP, supra note 6 .

197 Roper, 543 U.S. at 626-27; Youngjae Lee, International Consensus as Persuasive Authority in the Eighth Amendment, 156 U. PA. L. REV. 63, 75-78 (2007).

198 DE LA VEGA ET AL., supra note 30, at 26.

${ }^{199}$ Id. Indeed, only eight countries other than the United States allow both the death penalty and LWOP sentences: China, Comoros, Cuba, Israel, Kazakhstan, Lesotho, Nigeria, and Zimbabwe. Id. at 29.

${ }^{200}$ Id. at 8 (quoting International Covenant on Civil and Political Rights, supra note 139 , art. 10(3)).

${ }^{201}$ Rome Statute of the International Criminal Court art. 110(3), adopted July 1, 2002, 2187 U.N.T.S. 3.

202 Id. art. 5(1).

${ }^{203} I d$. at 4-6; DE LA VEGA ET AL., supra note 30, at 68.

204 DE LA VEGA ET AL., supra note 30, at 25.

205 See id. at 17.

${ }^{206}$ See id. at 25 n.144. These countries are Bulgaria, Hungary, Lithuania, Malta, the Netherlands, Slovakia, Sweden, Turkey, Ukraine, and the United Kingdom. LEIGEY, supra note 156 , at 20 . 
refuse extradition of an alleged offender if that offender faces an LWOP sentence. 207

The United States' LWOP population of over 41,000 offenders dwarfs that of other countries that permit LWOP. ${ }^{208}$ The nations with the next highest number of LWOP sentences-Australia, the Netherlands, and the United Kingdom-collectively have less than 150 offenders serving LWOP sentences. $^{209}$

Not only is the United States an outlier in the number of offenders serving LWOP sentences, but also in the kinds of crimes for which LWOP is a permissible sentence. ${ }^{210}$ Many countries require violent crimes for an LWOP sentence, and in some cases repeated violent offenses. ${ }^{211}$ England, for instance, requires premeditated murder of two or more people to be eligible for a LWOP sentence. ${ }^{212}$

The second part of the evolving standards of decency analysis under the Eighth Amendment asks whether any of the purposes of punishment justify the punishment in question. As demonstrated below, LWOP sentences do not clearly satisfy any of the purposes of punishment.

The purposes of punishment-retribution, deterrence, incapacitation, and rehabilitation - offer philosophical rationales for particular punishments, but do not specify a particular quantum of punishment. Andrew von Hirsch and Andrew Ashworth have argued that this is true with just deserts retributionone can rank punishments ordinally, but not provide cardinal values. ${ }^{213}$ In other words, one can determine the punishment for one crime should be more than another, but certain criminal acts do not demand a specific amount of punishment. ${ }^{214}$ It is difficult to say, for instance, whether an offender who commits armed robbery deserves ten years, twenty years, or some other punishment. ${ }^{215}$

With the most severe crimes, the purposes of punishment then begin to collapse, as a range of punishments with different levels of culpabilitycompare premeditated murder to genocide-will still warrant the same punishment, simply because that is the maximum punishment available. ${ }^{216}$

${ }^{207}$ Council Framework Decision 2002/584, art. 5(2), 2002 O.J. (L 190) 1, 4 (EC); DE LA VEGA ET AL., supra note 30, at 24.

208 DE LA VEGA ET AL., supra note 30, at 25.

${ }^{209}$ Id. Australia has fifty-nine LWOP sentences, England has thirty-seven, and the Netherlands has forty-one. Id.

210 Id. at 26.

211 Id.

212 Id.

213 Andrew VON Hirsch \& Andrew Ashworth, Proportionate Sentencing: EXPLORING THE PRINCIPLES 13 (2005).

214 Id.

215 Id.

${ }^{216}$ Id. at 14; Youngjae Lee, The Constitutional Right Against Excessive Punishment, 91 VA. L. REV. 677, 690-91 (2005). 
As a result, the purposes of punishment have diminishing value when considering punishments such as LWOP and the death penalty. ${ }^{217}$ The better question is where the punitive ceiling should be. ${ }^{218}$ Looking at the purposes of punishment individually with respect to LWOP underscores this point.

Given the many different strands of retribution, there are several ways to conceptualize an assessment of LWOP. If retribution is merely about revenge, it is difficult to imagine that a life sentence would serve to avenge a murder in the same way that the death penalty would. ${ }^{219}$ If, on the other hand, retribution is about giving an offender just deserts, LWOP becomes a more palatable option. ${ }^{220}$ Nonetheless, it is difficult to say, no matter the crime, that the definitive just deserts sentence is death in prison. ${ }^{221}$ Again, it depends on how one aligns the cardinal value of a sentence with the crime. ${ }^{222}$ In a non-capital jurisdiction, such a determination becomes simply the ceiling for punishments, and is not necessarily the prescribed punishment from a just deserts perspective. ${ }^{223}$

If one adopts a communicative version of just deserts, ${ }^{224}$ this becomes even more complicated, as it is difficult to say that the required metric of communication needs to be a death in prison sentence as opposed to some other sentence. ${ }^{225}$ Likewise, if under this approach, retribution may not require the death penalty, it is difficult to say that it requires LWOP. 226

With the utilitarian purposes of punishment, LWOP poses similar difficulties. As social science studies have shown with regard to capital punishment, ${ }^{227}$ it is unlikely that LWOP has a significant deterrent effect on crime. ${ }^{228}$ This is particularly true because LWOP is the lesser of two punishments in capital cases, so that if the death penalty does not deter, it is unlikely that LWOP does.

217 Youngjae Lee, The Purposes of Punishment Test, 23 Fed. SEnT'G ReP. 58, 59 (2010).

218 Model Penal Code: Sentencing 2 (Am. Law Inst., Tentative Draft No. 2, 2011); Norval Morris, Impediments to Penal Reform, 33 U. CHI. L. REV. 627, 639 (1966).

219 Cf. Furman v. Georgia, 408 U.S. 238, 343 (1972) (Marshall, J., concurring).

${ }^{220}$ Markel, supra note 152, at 422-24.

${ }^{221}$ VON HIRSCH \& ASHWORTH, supra note 213, at 13.

222 Id.

223 Id.

224 See Markel, supra note 152, at 428.

225 VON HIRSCH \& ASHWORTH, supra note 213, at 14.

${ }^{226}$ Markel, supra note 152, at 468.

227 See generally John J. Donohue \& Justin Wolfers, Uses and Abuses of Empirical Evidence in the Death Penalty Debate, 58 StAN. L. REV. 791 (2005); Carol S. Steiker, No, Capital Punishment Is Not Morally Required: Deterrence, Deontology, and the Death Penalty, 58 StAN. L. REV. 751 (2005). But see generally Cass R. Sunstein \& Adrian Vermeule, Is Capital Punishment Morally Required? Acts, Omissions, and Life-Life Tradeoffs, 58 STAN. L. REV. 703 (2005).

228 See, e.g., John J. Donohue III \& Justin Wolfers, The Death Penalty: No Evidence for Deterrence, 3 ECONOMIST's VOICE 1553 (2006). 
As for incapacitation, dangerousness estimates have a high likelihood of being inaccurate. ${ }^{229}$ Many estimates suggest that dangerousness estimates are only $50 \%$ accurate at best. 230 Given the difficulty of determining dangerousness, the risk of over and under inclusiveness in sentencing remains likely. ${ }^{231}$

Likewise with younger offenders, estimating dangerousness creates a difficult problem, as the likelihood of some maturation is high. ${ }^{232}$ Brain science demonstrates that complete social and emotional maturity does not occur until age twenty-five. ${ }^{233}$ Most criminal offenders have not reached that age. ${ }^{234}$ It is difficult, then, to measure one's future dangerousness given the uncertainty of physical and emotional development. ${ }^{235}$

A further problem is estimating the temporal end to one's dangerousness. ${ }^{236}$ Surely, most criminal offenders cease to be dangerous once reaching a certain elderly age, perhaps as the result of physical or mental declines. ${ }^{237}$ While some offenders may remain dangerous until they die, for many it is not likely to be the case. ${ }^{238}$ The sentencing question then becomes when one ceases to be dangerous.

LWOP sentences based upon dangerousness assume that (1) the offender has reached maturation, and (2) the offender will remain dangerous until they die, even if they have physical or mental declines. It is easy to see, then, why it

${ }^{229}$ Mitzi Dorland \& Daniel Krauss, The Danger of Dangerousness in Capital Sentencing: Exacerbating the Problem of Arbitrary and Capricious Decision-Making, 29 LAW \& PSYCHOL. ReV. 63, 66 (2005); Paul H. Robinson, Punishing Dangerousness: Cloaking Preventive Detention as Criminal Justice, 114 HARV. L. REV. 1429, 1432 (2001).

${ }^{230}$ See Brief for Am. Psychiatric Ass'n as Amicus Curiae Supporting Petitioner, Barefoot v. Estelle, 463 U.S. 880 (1983) (No. 82-6080), 1983 U.S. S. Ct. Briefs LEXIS 1529 , at $* 14$ [hereinafter APA Brief] ("The large body of research in this area indicates that, even under the best of conditions, psychiatric predictions of long-term future dangerousness are wrong in at least two out of every three cases."); Berry, supra note 42, at 907-08.

${ }^{231}$ Robinson, supra note 229, at 1432; Meghan Shapiro, An Overdose of Dangerousness: How "Future Dangerousness" Catches the Least Culpable Capital Defendants and Undermines the Rationale for the Executions It Supports, 35 AM. J. CRIM. L. 145, 148 (2008).

232 Rolf Loeber et al., Findings from the Pittsburgh Youth Study: Cognitive Impulsivity and Intelligence as Predictors of Age-Crime Curve, 51 J. AM. ACAD. CHILD \& ADOLESCENT PSYCHIATRY 1136, 1146-47 (2012).

233 M. Brent Donnellan et al., Cognitive Abilities in Adolescent-Limited and LifeCourse-Persistent Criminal Offenders, 109 J. ABNORMAL PSYCHOL. 396, 398 (2000).

234 Travis Hirschi \& Michael Gottfredson, Age and the Explanation of Crime, 89 AM. J. SoC. 552, 574-75 (1983).

235 Donnellan et al., supra note 233, at 398; Loeber et al., supra note 232, at 1137.

${ }^{236}$ Darrell Steffensmeier et al., Age Differences in Sentencing, 12 JuST. Q. 583, 587 (1995).

${ }^{237}$ Molly Fairchild James, The Sentencing of Elderly Criminals, 29 AM. CRIM. L. REV. 1025, 1038 (1992).

238 Id. 
is difficult to determine to any level of certainty that a particular offender will be dangerous for the rest of his life. 239

Finally, LWOP sentences overtly abandon the utilitarian purpose of rehabilitation. By definition, LWOP sentences decide that the level of rehabilitation that an offender could receive will never reach a level such that the offender can rejoin society. For the LWOP offender, then, rehabilitation becomes a moot consideration, at least with respect to the possibility of release, which does not exist for such offenders.

\section{The Presence of Reasonable Alternatives}

Even if one does not find that LWOP sentences violate human rights or constitute cruel and unusual punishments, it is still worth considering abolition because of the presence of reasonable alternatives. As explained below, the decision that an offender should spend his life in prison does not have to be a one-time decision that will never be revisited.

\section{Time Is on the State's Side}

In capital cases, the state kills the offender. In such situations, the review of the sentence becomes moot, as the offender is dead. ${ }^{240}$ As a result, states attempt to provide exhaustive review of cases prior to execution. ${ }^{241}$ This process often takes over a decade. ${ }^{242}$

In LWOP cases, by contrast, the only temporal limitation to examining a case is the life span of the offender. In other words, the state has ample time to revisit sentencing decisions in such cases.

The practical impact of this reality, however, is that courts generally ignore such cases after the initial sentencing decision because the sentence is not a capital one. ${ }^{243}$ As a result, the LWOP sentences, despite their condemnation as death in state custody, seldom receive the kind of scrutiny that capital cases do, and are rarely reversed on appeal. ${ }^{244}$

Even so, the slow process by which offenders with LWOP sentences serve them-until death by natural causes - affords ample time to revisit the sentence at a later date to determine whether the state should release the

239 APA Brief, supra note 230, at*14; Robinson, supra note 229, at 1432 .

240 The Supreme Court has long held that "death is different" for this reasonexecutions are final and irrevocable. See supra note 110 and accompanying text.

241 This process is still rife with difficulties, as the number of innocent offenders on death row has been quite high, as well as the error rate in such cases. See BRANDON L. Garrett, Convicting the InNocent: Where Criminal Prosecutions Go Wrong 1113 (2011); Gelman et al., supra note 35, at 260.

242 Time on Death Row, DEATH PENALTY INFO. CTR., http://www.deathpenaltyinfo.org/ time-death-row [http://perma.cc/G6HL-R46W].

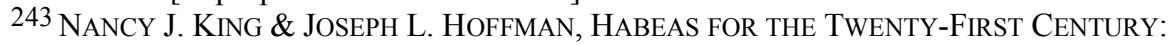
USES, ABUSES, AND THE FUTURE OF THE GREAT WRIT 73-75 (2011).

244 Id. 
offender. Kicking the final decision down the road does not cost the state anything, as it can always decide not to release the offender. On the other hand, simply providing an opportunity for revisiting the sentence at a later date can mean everything for the offender-providing some hope for release as opposed to no hope for release. ${ }^{245}$

\section{The Limits of Sentencing at Trial}

Determining the appropriate criminal sentence becomes difficult in cases toward the more punitive end of the spectrum. ${ }^{246}$ While in many American states the likely sentence for an aggravated murderer is LWOP or the death penalty, other countries impose far lesser sentences for the most serious crimes. ${ }^{247}$ In Norway, for example, Anders Breivik went on a killing spree, murdering seventy-seven people, but received a sentence of twenty-one years, the maximum allowed under Norwegian law. ${ }^{248}$

In other words, serious crimes do not mandate certain penalties. For such crimes, the top of the permissible sentencing range often becomes the applicable sentence. As explained above, the ICC restricts punishments for genocide, war crimes, and crimes against humanity to life with the possibility of parole after twenty-five years. ${ }^{249}$

But it is not clear that a certain sentence arises from a certain crime. ${ }^{250}$ As a result, giving the sentence a "second-look" at a later date allows the judge or parole board to re-examine the punishment anew. ${ }^{251}$ This has the advantage of having distance from the emotional reaction to the crime that occurs in its aftermath. All too often the fury of the response to the offender's transgression pushes the judge or jury to choose the most severe punishment. ${ }^{252}$

At the initial time of sentencing, it is difficult to determine what sentence is sufficient for such an offender. The court's attempt to envisage whether the offender will ever be capable of rejoining society, particularly after a decade or more in state custody, seems to be conjectural at best.

Engaging in a second or third look at the sentence allows the judge or jury to consider the effect to date of the sentence on the offender. Part of this analysis is whether the sentence to date has been sufficient to achieve the punitive goal. Similarly, this analysis can explore the degree to which the

245 Appleton \& Grøver, supra note 11, at 604; Ristroph, supra note 118, at 75.

246 VON HIRSCH \& ASHWORTH, supra note 213, at 13-14.

247 DE LA VEGA ET AL., supra note 30, at 26.

${ }^{248}$ Mark Lewis \& Sarah Lyall, Norway Mass Killer Gets the Maximum: 21 Years, N.Y. TIMES (Aug. 24, 2012), http:/www.nytimes.com/2012/08/25/world/europe/andersbehring-breivik-murder-trial.html?_r=0 [http://perma.cc/k8MG-957F].

249 See DE LA VEGA ET AL., supra note 30, at 23.

250 VON HIRSCH \& ASHWORTH, supra note 213, at 12.

${ }^{251}$ Frase, supra note 163, at 195.

252 Denny Chin, Sentencing: A Role for Empathy, 160 U. PA. L. REV. 1561, 1577 (2012) (citing United States v. Leung, 360 F.3d 62, 64-65 (2d Cir. 2004)). 
offender has changed or grown during his incarceration, and whether such development warrants release.

The American Law Institute, in the most recent draft of the Model Penal Code, has recognized this difficulty. ${ }^{253}$ In the most recent tentative draft of the next version of the code, draft section 305.6 announces principles for legislation with respect to long-term prison sentences. ${ }^{254}$ While not calling for abolition of LWOP sentences in all circumstances, as proposed herein, ${ }^{255}$ the Institute does propose giving offenders the opportunity for sentence modification after fifteen years. ${ }^{256}$ The relevant part of its proposal explains:

Sentence modification under this provision should be viewed as analogous to a resentencing in light of present circumstances. The inquiry shall be whether the purposes of sentencing in $\S 1.02(2)$ would better be served by a modified sentence than the prisoner's completion of the original sentence. The judicial panel or other judicial decisionmaker may adopt procedures for the screening and dismissal of applications that are unmeritorious on their face under this standard. ${ }^{257}$

The drafters here clearly express the sentiment that for long-term prison sentences (although not LWOP), courts should re-examine the sentence to determine whether it deserves some kind of modification. ${ }^{258}$

Instead of merely creating a safety valve to modify lengthy sentences, this article proposes the abolition of LWOP and articulates below a model for creating varying levels of presumptive life sentences.

\section{Presumptive Life Sentences as the LWOP Alternative}

Given the shortcomings of LWOP sentences and the need for an alternative, this section proposes an alternative to LWOP: presumptive life sentences. As discussed below, this proposal aims to cure the LWOP epidemic without undermining the capital punishment abolition movement and without increasing the volume of dangerous criminals in society.

253 Model Penal Code: Sentencing $§ 6.06$ (Am. Law InSt., Tentative Draft No. 2, 2011).

254 Id. § 305.6.

255 Id. $\S 6.06$.

256 Id.

${ }^{257}$ Id. § 305.6 .

${ }^{258}$ Id. American Law Institute makes clear that the modification could only go in one direction-increased leniency. $I d$. $\S 305.6 \mathrm{cmt}$. g ("305.6 is designed to operate only in the direction of lenity."). The revisiting of the sentence would not provide the opportunity to increase the sentence. Id. 


\section{A. The Proposal}

Presumptive life sentences should replace LWOP sentences as the most serious alternative to capital punishment. Such sentences would aim to bifurcate the sentencing procedure with respect to the most serious felonies such that any sentencing decision of such magnitude would receive de novo review of its merits.

Awarded at sentencing, presumptive life sentences would first combine a fixed term of years, followed by a second decision about whether the offender should serve an additional fixed term of years.

Second, the decision about whether to sentence the offender to an additional term of years would return to the original sentencing court. The same court would conduct a sentencing hearing, similar to that after trial, to determine the appropriate future sentence. 259

Third, for offenders receiving a presumptive life sentence, the presumption at the second sentencing hearing would be that the offender would serve an additional term of years. The offender, though, could overcome that presumption by demonstrating that he or she deserved to return to society.

The goal, then, would be to bifurcate the sentencing decision in serious criminal cases. The presumption and term of years could relate to the crime committed by the offender. Non-violent drug offenders might have a shorter term of years and a weaker presumption against an additional term of years. Aggravated murderers, on the other hand, would likely have a longer initial term of years, and have a higher burden to overcome the presumption of a life sentence.

For instance, a state could develop a system with different tiers of presumptive life sentences: non-violent offenders, violent offenders, and the "worst of the worst" offenders. For all categories, the second part of the sentencing would occur after 15 years. For non-violent offenders, the presumption would be that the state would release the offender, with the state having the burden to demonstrate that the offender deserved an additional tenyear term. For violent offenders, the presumption would be that the state would not release the offender, and the offender would serve an additional tenyear term, unless the offender could prove by a preponderance of the evidence that additional incarceration was unnecessary. For the "worst of the worst" offender, the presumption of continued incarceration would be higher, and another ten-year sentence would commence unless the offender could demonstrate by clear and convincing evidence that additional incarceration was unnecessary.

For all categories of offenders, another sentencing hearing would occur after another decade, following the same rules. Under such a system, all offenders would have an opportunity for release once a decade, but would

${ }^{259}$ An alternative model would be to have a separate court delineated to address such issues. 
have to establish that they deserved release, particularly in the case of violent offenders. For the worst offenders, the increased burden would make release unlikely, except in rare circumstances.

\section{B. Why the Proposal Cures the LWOP Epidemic}

Substituting presumptive life sentences for LWOP sentences has the potential to cure the LWOP epidemic. First, bifurcating the sentence increases the ability to sentence offenders more individually and accurately, rather than lumping a large number of offenders into a one-size-fits-all category. This approach expands the individualized sentencing ideal expressed in Lockett $v$. Ohio and Woodson v. North Carolina, ${ }^{260}$ and allows the final sentence to include consideration of the offender's actions and life after imprisonment. For some deserving prisoners, this will afford the opportunity at having some semblance of a life.

Second, the bifurcated sentencing approach allows for a determination of the offender's ability to change over time, as the court has an additional data point beyond the initial sentencing hearing. It gives the offender a chance to show that he deserves to be defined by something more that his worst transgression.

The proposal then eliminates the human rights problem of LWOP-it accords all offenders a quantum of human dignity. The presumptive life sentences are life-with-hope sentences-providing some opportunity for redemption for all offenders.

As the Court pointed out in Vinter, life imprisonment by itself does not violate human rights. Rather, it is the one-time decision, never revisited, that compromises the offender's dignity. By revisiting the sentence once a decade, the state takes the life of the offender seriously, and offers hope, albeit narrow in some cases, for reform.

At the same time, presumptive life sentences require the careful review of the character and rehabilitation of offenders prior to allowing their release. The courts will have the ability to release offenders who are less likely to reoffend, while keeping more violent individuals incapacitated.

Also important is the amount of time between the initial sentence and the second part of the hearing. The situation of the offender after fifteen years provides a different calculus, particularly given the decreased likelihood of recidivism as criminal offenders age. ${ }^{261}$ Most offenders will be in their midthirties and will have had sufficient opportunity to mature. For older offenders, the likelihood of reoffending diminishes significantly among sixty- and

${ }^{260}$ Lockett v. Ohio, 438 U.S. 586, 604-05 (1978) (holding that the Eighth Amendment prohibits limitations on the introduction of mitigating evidence at sentencing); Woodson $\mathrm{v}$. North Carolina, 428 U.S. 280, 301 (1976) (holding that the Eighth Amendment prohibits a mandatory death penalty because the Constitution requires individualized sentencing determinations).

${ }^{261}$ See NELLIS \& KING, supra note 18, at 36; Lerner, supra note 7, at 1154. 
seventy-year-old inmates. ${ }^{262}$ Without a doubt, the decision-making calculus as to the need to incarcerate certain offenders shifts over time. This will allow courts to make a better judgment as to whether the offender should continue to remain behind bars.

\section{The Risks of the Proposal (and Why They Are Worth Taking)}

The most obvious risk of adopting presumptive life sentences and abolishing LWOP sentences is that dangerous offenders will rejoin society and reoffend, perhaps in brutal and horrific ways. Certainly, such occurrences will counsel against this approach and convince many that LWOP provides a better solution.

While real, it is easy to overstate such a risk, particularly based upon the fear of offenders. One occurrence does not make a rule - and the court serves as a shield against particularly dangerous offenders.

Further, this fear ignores the diminishing likelihood of widespread crime sprees by released offenders, many of whom will be middle-aged, if not elderly. In other words, while one can make the case for fearing certain offenders in the aftermath of vicious crimes, it seems at some point many cease to be so dangerous.

Further, one must weigh the risk of reoffending, stemming from a culture of fear of criminal offenders, against the complete condemnation of the criminal offender. The penal populism movement over the past three decades in the United States clearly demonstrates the propensity for excessive punishment in the name of incapacitation of dangerous offenders.

The cost of the incarceration state from a moral perspective is the overpunishment of offenders, particularly those from poor and/or minority backgrounds. Labeling such offenders as "criminal others" gives license to fear them unreasonably and consequently over-punish them. Eliminating LWOP sentences mitigates some of this irrational over-punishment in a principled, rational way while still considering the safety of society.

A second major objection to the adoption of presumptive life sentences would be the excess cost of additional judicial proceedings. The fear would be that presumptive life cases would turn LWOP cases into the financial drain of capital cases.

On the one hand, the additional scrutiny might achieve significantly more justice in the criminal justice system. If a carefully reviewed capital system yields an error rate of almost seventy percent in capital cases, ${ }^{263}$ it is unreasonable to assume a vastly different scenario in LWOP cases. Indeed, the main difference may be the comparative lack of appellate scrutiny that LWOP sentences receive. In addition, LWOP offenders do not have the right to appellate counsel, impairing their access to further review of their cases.

262 See, e.g., NELLIS \& KING, supra note 18, at 37-38.

263 See Gelman et al., supra note 35, at 261. 
It is possible, as well, that the release of some offenders, most likely nonviolent offenders, would save the state some of the costs of incarceration associated with LWOP. Such savings would likely not completely offset the increased costs, but might help to defray them.

Even if review did not reveal errors and simply served to drive up judicial costs, the dignity of the offenders demands such care. The decision to imprison an offender for life is not a decision states should take lightly, and reviewing the cases once a decade does not seem to be too significant a burden in light of the seriousness of the consequence for the offender.

In the final analysis, neither the risks of releasing dangerous offenders nor the increased administrative and legal costs outweigh the human rights of the offender. The presumptive life sentence approach advocated here helps assure that the state accords criminal offenders a modicum of dignity in the administration of criminal justice.

\section{CONCLUSION}

This Article has made the case for the abolition of LWOP sentences. After explaining the perfect storm that led to this epidemic in the United States, the Article demonstrated why such sentences violate the human rights of criminal offenders. Having shown the shortcomings of LWOP sentences, the Article then proposed an alternative - presumptive life sentences - and explained why this alternative would remedy the human rights issue without unduly compromising the safety of citizens.

In the end, this Article simply seeks to provide all criminal offenders some level of hope for redemption. To remedy, then, the many faults of LWOP sentences - a death sentence that gives no hope - states should replace LWOP with life-with-hope sentences in the form of presumptive life sentences. 